\title{
Planning and Settlement Conditions for the Development of Renewable Energy Sources in Poland: Conclusions for Local and Regional Policy
}

\author{
Przemysław Śleszyński ${ }^{1}{ }^{(D}$, Maciej Nowak $^{2}{ }^{\circledR}$, Agnieszka Brelik $^{3}{ }^{\circledR}$, Bartosz Mickiewicz $^{3}$ \\ and Natalia Oleszczyk ${ }^{3, *}$ \\ 1 Institute of Geography and Spatial Organization, Polish Academy of Sciences, Twarda 51/55, \\ 00-818 Warsaw, Poland; psleszyn@twarda.pan.pl \\ 2 Department of Real Estate, Faculty of Economics, West Pomeranian University of Technology, Żołnierska 47, \\ 70-310 Szczecin, Poland; Maciej.Nowak@zut.edu.pl \\ 3 Department of Regional and European Studies, Faculty of Economics, \\ West Pomeranian University of Technology, Żołnierska 47, 70-310 Szczecin, Poland; \\ Agnieszka.Brelik@zut.edu.pl (A.B.); bartosz.mickiewicz@zut.edu.pl (B.M.) \\ * Correspondence: natalia.oleszczyk@zut.edu.pl
}

Citation: Śleszyński, P.; Nowak, M.; Brelik, A.; Mickiewicz, B.; Oleszczyk, N. Planning and Settlement

Conditions for the Development of Renewable Energy Sources in Poland: Conclusions for Local and Regional

Policy. Energies 2021, 14, 1935.

https://doi.org/10.3390/en14071935

Academic Editor: Maarten Wolsink

Received: 25 February 2021

Accepted: 27 March 2021

Published: 31 March 2021

Publisher's Note: MDPI stays neutral with regard to jurisdictional claims in published maps and institutional affiliations.

Copyright: (c) 2021 by the authors. Licensee MDPI, Basel, Switzerland. This article is an open access article distributed under the terms and conditions of the Creative Commons Attribution (CC BY) license (https:// creativecommons.org/licenses/by/ $4.0 /)$.

\begin{abstract}
The article presents an analysis of geographical-settlement and legal-planning conditions for the development of Poland's distributed generation. The choice of this country is important and interesting due to the highly dispersed settlement, which may be a factor stimulating the development of this type of energy systems. For this reason, the analysis can be a model for other countries and regions, indicating ways to analyze and evaluate settlement and planning conditions for the development of renewable and distributed energy. At the same time, Poland is struggling with a severe crisis of spatial planning. By analysing these opportunities and threats, empirical analyses try to indicate regularities in this respect in Poland's regions in a detailed approach to communes and detailed legal and planning conditions. The conclusions emphasise the usefulness of distributed generation development for peripheral and sparsely populated areas of Europe and other parts of the world and appropriate directions of changes in spatial development law.
\end{abstract}

Keywords: distributed generation; settlement systems; local development

\section{Introduction}

The currently observed strong changes in the world's energy sector make it necessary to reconstruct current local and regional development views adequately. It applies especially to Poland, where when the world is experiencing an increasingly advanced energy evolution, most of the energy produced is still obtained from non-renewable sources, including geographically concentrated large professional thermal power plants (over $70 \%$ of electricity in 2019). It is deeply embedded in this country's history, including the model of economic development chosen after World War II in the conditions of a command and distribution system, consisting in the development of particularly energy-intensive industries, and accelerated industrialisation [1,2]. Meanwhile, most of the more developed countries have been observing a reorientation towards renewable energy sources (RES) for at least two decades and a strongly related shift towards the deconcentration of energy production, especially in rural and urban-rural transition areas [3].

At the same time, apart from the development of transport systems, energy production is one of the fundamental factors determining the operation of infrastructure and the movement of people and goods, and thus economic and social development. Hence, ensuring optimal conditions for the development of energy and energy use becomes a fundamental issue that also determines appropriate spatial development. 
With the problem formulated in this way, the article aims to identify barriers and stimulants for the development of renewable energy in Poland, resulting from the settlement, demographic, economic and formal-legal conditions of the spatial management system. The research objective is also an attempt to find an answer to the extent to which communes secure the areas for possible functions related to energy. It is an important issue of a demand and supply nature, related to investment opportunities on the one hand and spatial (and development) policies of local governments on the other. It is the dimension of spatial policies that significantly determines the development of renewable energy in Poland. The significant relationship of the indicated issues is confirmed by the latest Territorial Agenda of the European Union 2030 [4]. The possibilities of locating the energy sector guaranteed by the national spatial management systems are determined by the priorities of "Fair Europe" and "Green Europe" included in the Agenda (regardless of the above, renewable energy is promoted in other EU acts and documents [5]).

Considering the above goals, the following research questions were formulated:

(1) How does spatial policy in Poland determine the development of distributed renewable energy? In which ranges is it positive and stimulating, and in which negative and destimulating?

(2) In which parts of the country is the planning situation better organised, and are there any regularities related to communes' morphological and functional specificity?

(3) In which regions of the country should the settlement structure be particularly suited to developing dispersed renewable energy?

(4) What legal and planning actions should be taken to promote the development of distributed renewable energy more effectively?

To answer these questions, in the empirical part, based on data on the development of settlement in Poland, the correlation between the dispersion of settlement and the expansion and reduction of energy emissions will be determined. In this context, Poland's choice as a research field is important and interesting for several reasons. First, it is the largest country in Central Europe, undergoing the so-called political transformation after 1989 and the economic system's change from command and distribution (centrally controlled) to a free-market one. Secondly, this country struggles with a crisis in spatial management, and the scale of neglect in spatial planning is one of the largest in Europe [6,7]. It may cause significant barriers to the development of renewable energy. Finding and describing them should answer how to avoid and prevent such problems in other countries. Thirdly, Poland is characterised by a highly dispersed settlement arrangement [8], which is constantly deepening today $[9,10]$, which translates into a different energy demand structure.

There follows a premise: the main thesis and the guiding axis of the article that Poland's settlement structure, especially in rural areas, may be a significant stimulator of distributed generation of renewable energy. In the opinion of the authors, this problem is insufficiently researched, and it can be a model for other countries and regions by indicating the ways of analysis and evaluation of settlement and planning conditions for the development of renewable and distributed energy. It is connected with better efficiency of energy systems and broadly understood spatial organization as well as with energy security. The literature highlights the mismatch between broadly defined spatial structures and the challenges of both natural processes (especially climate change) and civilization change [7]. This problem may be exacerbated by the post-COVID-19 pandemic situation, as changes in the mobility of societies and locations of residence are predicted, involving a greater desire to live in less populated areas, with lower population densities, in smaller towns and villages [11].

These issues are connected to the challenges of public policies, especially spatial policies (which is also the perspective of this article). It must be emphasized that the implementation of RES investments, as well as other demands (such as those mentioned above, included in the Territorial Agenda 2030) require adaptation and efficiency of specific spatial policy tools [12-14]. Also in this context, the Polish example is very goodbecause it includes a system containing numerous inefficiencies of public authorities. 
The article indicates the relationship between these (presented) manifestations of inefficiencies of public authorities and spatial policy tools and the real possibilities of RES investment implementation.

The findings in the first part of the article will be related to the legal framework for the location of renewable energy sources (and the planning problems that arise on this occasion). Recognition of renewable energy sources in the legal framework required modification of the scope of spatial policy tools, also covering the sphere of development of other areas. In this regard, the article identifies possible spatial conflicts between the location of renewable energy sources and the implementation of other functions of individual areas.

The article firstly analyses determinants of renewable energy development in Poland against the background of global trends. Especially the European context was taken into account. Then the methods were described. The next part includes the characteristics of planning and settlement conditions in Poland. These parts, apart from referring to the literature and legal regulations, contain the results of the study. The results are discussed. The conclusions include a summary and recommendations for spatial policies.

\section{Determinants of Renewable Energy Development in Poland against the Background of Global Trends}

The literature on the subject repeatedly points to the significant role of renewable energy sources in social and economic development [15]. It is also why the role of national policy and national conditions in shaping the energy market is so important [16-18]. This role must often be reduced to various public authorities activities related to the economic policy of states and regions [15-17]. In this context, it is particularly important to emphasise the energy policy's role, also related to increasing the share of renewable energy in total energy consumption [18]. Undoubtedly, the reference point on this occasion will be income and energy consumption [19,20]. Among the key objectives of RES development are both issues related to efficient management and ensuring wider environmental protection [21]. Besides, RES have a very wide potential, broadly responding to diverse forms of urban demand [22,23]. This provides a basis for further postulates related to different contexts of RES analyses and their effects [24], also in the context of linking public policies with innovations.

Depending on the specificity of individual countries, the possibilities of obtaining income and increasing the share of renewable energy directly depend on these countries. The reasons for such differentiation may be broadly understood as natural conditions and economic profitability [25-27]. Despite these differences, the very fact of the growing role of renewable energy is beyond doubt, for example, in the context of the development of rural areas, the development of the local energy value chain [28-32], as well as mitigating climate change and greater care for the environment [33]. Recent studies also highlight the important role of RES in the context of COVID-19 impacts [34].

In this context, we come to the issue of important determinants of distributed generation (DG), which include sources located independent of central planning and, at the same time, with powers in the range most often from $15 \mathrm{~kW}$ to $10 \mathrm{MW}$ [35-37]. Renewable energy sources create specific conditions for the development of DG. They can be used by medium and low-power plants located near consumers. Currently, apart from energy production costs, there is also a technical barrier [38] to the development of distributed energy and investment risk in competitive energy markets [39].

In Poland's case, the power system's current shape, adapted to large generating units, is a serious problem (Polish coal-fired commercial power plants are among the largest in Europe) [40]. The inclusion in the DG system of small units generating energy with different technical parameters and the amount of energy production varying in time makes it difficult to control and monitor the entire system. However, their implementation may bring many technical, economic and environmental benefits, such as power improvement, reliability, system safety, reduction of high-level investment outlays, or reduction of greenhouse gas emissions $[36,37,41]$. 
The literature points to numerous problems when conducting research in the aforementioned area. These include lack of knowledge on appropriate research software, broader classifications and typologies of renewable and non-renewable sources, as well as shortages in the literature on the subject [42]. It seems all the more appropriate to approach this problem in different contexts, including those related to settlement and spatial policy. The role of public authorities can be understood very broadly, for example, by increasing the importance of the regional and local level (e.g., through appropriate legislative initiatives that give more freedom in the organisation of local energy systems and independence from the monopoly of energy suppliers). Increasing distributed energy resources at this level is equivalent to the need to reorganise centralised energy systems in many cases [43]. Also thanks to the tools of spatial policy, diversified incentives (considered crucial in the literature [44]) may be developed for the implementation-both on a national, regional and local scale-of RES investments.

The above problem is well illustrated by the changes that have taken place in Poland since accession to the European Union (2004) in connection with the increasing share of energy production from renewable sources (Figure 1). Data are available for 16 voivodships, which were grouped into 3 clusters according to urbanization level. In the less urbanized regions, the level was the highest, but it stopped at the same level since 2014. The lowest share was in the most urbanized provinces, which is due to higher energy demand, including the location of industry. Meanwhile, these provinces through conventional power plants contribute the most to environmental pollution, smog, etc. For example, the most heavily industrialized Ślaskie (Silesian) voivodship produced 21.6 TWh of electricity in 2019 , while the share of renevable energy was only $4.4 \%$. This example shows how serious the problem is the structure of energy production in Poland in relation to the settlement system of the country.

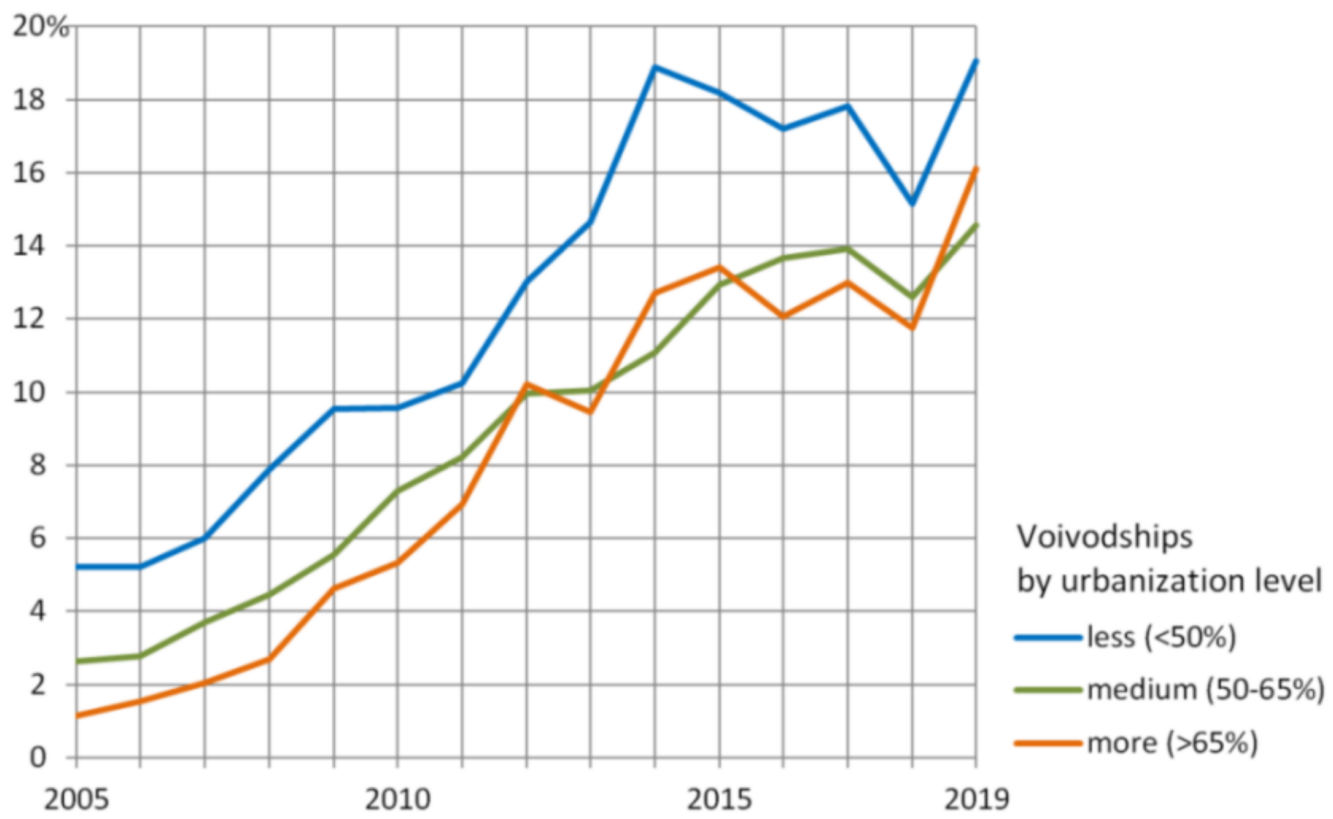

Figure 1. Share of energy production from renewable sources in Poland in 2005-2019 by level of urbanisation of provinces.Source: based on data from Local Data Bank of Central Statistical Office of Poland.

Therefore, there is no doubt that the issues mentioned above are important from both a national and local perspective. In the latter context, it is related to the issues of spatial policies [45]. As a rule, planning authorities act as energy users, participants of the competitive energy market, local energy regulators, and investors and energy producers [46-49]. The local authorities can stimulate local communities to generate renewable energy for 
their needs [50]. The state must support the development of the energy sector in a way that enables the achievement of specific socio-economic goals at the national, regional and local level, which is partly at odds with the principles of economic freedom and competition in the energy market [51].

The literature indicates that the location of a particular power plant itself is important from a variety of perspectives [52]. Besides the question of location, other important issues may be connected with the requirements of spatial policy. One of them may be the attempt to define comprehensive urban energy planning, especially adapting it to predictable changes in the environment [22]. However, the very aspect of integrating energy policy with environmental protection is also important [20]. The basis for an adequate connection of these spheres, apart from the demands of individual solutions $[53,54]$, may be an adequate spatial policy. It is from the perspective of specific spatial policy actors that it will be possible to propose solutions to reconcile potential collisions of various policies and potential spatial conflicts.

Issues related to the verification of RES development for Central European countries were the subject of research. They show, among other things, that in all countries the use of renewable energy generally has a positive impact on economic growth. In some cases, the lack of some unambiguous statistical confirmation is due to the smaller scope of renewable energy in these countries compared to other EU member states [55]. Besides, internal variations also occur in the countries of Central and Eastern Europe [56]. They also result from settlement characteristics. A particularly important condition is that Poland belongs to the countries with a local settlement's dispersed structure. It applies to both typical rural areas and urban areas and, to a large extent, cities of various sizes. The dispersion conditions are different for each of these settlement types: historical [57] and contemporary [10]. The highly dispersed development is the basic reason for the high operating costs of the technical and social infrastructure intended for its operation [58]. Against the background of the Central European region, Poland has the lowest renevable energy share index (12.2). It should also be noted that this share increased between 2004 and 2019 by only 5.3 percentage points (in the other four countries, i.e., Austria, Czechia, Hungary, Slovakia-by 8.3-11.1 pp.). These results show the importance of Poland catching up with the requirements of Directive (EU) 2018/2001 of the European Parliament and of the Council of 11 December 2018. At the same time, it justifies undertaking studies that could accelerate the achievement of this objective.

\section{Materials and Methods}

The empirical analyses used unique data from the survey. The Central Statistical Office sends to all municipalities (gminas) in Poland (2477 units in 2019) to cooperate with the ministry responsible for spatial management. These data show the planned directions of land use in communes in two types of planning documents: studies of the conditions and directions of spatial development (commune studies) and local spatial development plans (local plans). In this, the key question about the share of land intended for industrial functions (allowing the construction of small power plants) was answered in 2019 by 2302 units (nearly 93\%), and of the 2325 municipalities with at least one local plan-2302 (i.e., almost all). All larger cities were excluded from the analysis (i.e., cities with poviat rights, where the conditions for the development of energy based on RES are significantly different from those occurring in rural areas, urban-rural transition areas and smaller towns.

According to the existing regulations, there is no strict definition of production sites in the municipal study. It is treated by default as related to industrial production and facilities (warehouses, stores). On the other hand, local plans use the category of "technical and product development areas", which include "areas of production facilities and warehouses" and "mining areas". 
In part concerning settlement analysis, data on the distribution of buildings and the average distances between them were used. The data was obtained from the Database of Topographical Objects (BDOT). A detailed description of this source can be found in [10].

Besides, data on the tangible effects of investments were used, i.e., the usable floor area of buildings completed, broken down into residential and non-residential buildings (data based on the Local Data Bank of the Central Statistical Office of Poland). Data exclude non-residential farm buildings.

The analyses used the communes' classification into ten types, prepared especially to monitor spatial planning [59]. This classification was developed based on the deductiveinductive method. A settlement system forms the "skeleton" with different administrative and functional hierarchy levels. The remaining types of communes are separated mainly because of their socio-economic functions and morphological features (Table 1).

\section{Results-Determinants of the Location of Renewable Energy Sources in Poland 4.1. Planning Conditions}

The Polish spatial planning system's numerous weaknesses have been pointed out for years [60-62]. They have recently been expressed by defining and distinguishing the specific costs of spatial chaos [10]. At the local level, three direct spatial policy tools are distinguished: studies of the conditions and directions of spatial development, local spatial development plans and decisions on building conditions and land development. The studies of the conditions and directions of spatial development are documents of a creative and conceptual nature. The regulatory action is the local spatial development plans, which bind the purpose and principles of land development. However, local plans are not obligatory: municipal authorities freely decide on their adoption. Often barriers to their enactment are concerns about the compensation consequences that municipalities would have to pay to property owners.

A problem in the Polish spatial management system is that studies of the conditions and directions of spatial development have limited impact. Their provisions are only binding for local spatial development plans. However, local plans are not obligatory (and have not been enacted in most parts of Poland). In this situation, many municipalities do not create a broader spatial policy. On the other hand, even the fact of enacting local plans is not synonymous with positive effects. Very often, local plans are constructed incorrectly (and cause doubts in interpretation [63]). Many municipalities, fearing claims of property owners, allow too wide development in their local plans.

Moreover, spatial policy tools at the local level are still not sufficiently integrated with other policy acts, such as local development strategies [64]. It is possible (and often happens) that such documents diverge completely. In the Polish spatial development law there is a principle of municipality independence. This means that the municipality may shape the local space on its own, unless the specific possibilities of interference are directly assigned to the supra-local level of government. At the same time, the Polish spatial planning system strongly (in the authors' opinion too strongly) protects the individual rights of property owners [65]. It contributes to numerous spatial conflicts and barriers to the protection of spatial order [66].

On the other hand, in a situation when a local plan does not cover a given area, an administrative decision becomes a specific counterpart of the plan (a decision on building conditions and land development, completely 'detached' from the local planning order, often independent of the content of the study of conditions and directions of spatial development [67]. Such decisions protect the spatial order even less than other spatial policy tools [68]. In order to issue such decisions, municipalities must verify whether the criteria set forth in the law are met. In practice, these criteria are formulated in very general terms and in different cases they are interpreted quite differently. 
Table 1. Characteristics of the analysed communes (gminas) in Poland, for the year 2019.

\begin{tabular}{ccccc}
\hline Type * & $\begin{array}{c}\text { Included in the } \\
\text { Analysis }\end{array}$ & $\begin{array}{c}\text { Number of } \\
\text { Communes }\end{array}$ & Area (km²) & $\begin{array}{c}\text { Population } \\
\text { (Thous.) }\end{array}$ \\
\hline A & No & 33 & 5004 & 9563 \\
B & Yes & 265 & 27,589 & 4873 \\
C & No & 55 & 3399 & 4322 \\
D & Yes & 201 & 21,468 & 2452 \\
E & Yes & 142 & 10,265 & 3783 \\
F & Yes & 137 & 19,964 & 1435 \\
G & Yes & 222 & 33,856 & 1817 \\
H & Yes & 496 & 62,971 & 3048 \\
I & Yes & 665 & 86,532 & 5179 \\
J & Yes & 261 & 41,657 & 1910 \\
& Total (Poland) & $96.4 \%$ & 312,705 & 38,383 \\
& Total \% (“Yes") & $97.3 \%$ & $63.8 \%$ \\
\hline
\end{tabular}

* A-functional urban areas of voivodeship capitals; B-their external zones; C-functional urban; areas of subregional centres; D-their external zones; E-multifunctional urban centres; F-gminas (communes) with developed transport functions; G-gminas with other developed non-agricultural functions (tourism and largescale functions, including mining); $\mathrm{H}$-gminas with intensively developed agricultural functions; I-gminas with moderately developed agricultural functions; J-extensively developed gminas (with forests or nature protection areas). Source: based on Śleszyński and Komornicki classification [65] and data from the Ministry of Development and Central Statistical Office of Poland.

The basic planning order shaped in this way in Poland is modified by numerous sectoral laws. The conditions for the implementation of individual investments are also influenced in a different way. This also applies to investments in renewable energy sources. Problems occur with both the use of local plans and location decisions. In the case of local plans, the investments in question are presented in an inconsistent manner. A frequent tendency is limiting the scope of RES investments, as well as including them in an unclear, undefined way. This causes specific barriers in the implementation of investments [69]. Changing investment needs (or the need to clarify them) will usually require a timeconsuming amendment to the local plan.

On the other hand, potentially overly broad permissions for designated investments in local plans exacerbate spatial conflicts. The situation is even worse in the case of RES investments carried out on the basis of decisions on development conditions. Judicial decisions on the conditions of considering investments under this procedure are very diverse, which creates chaos when applying specific criteria.

The Polish legislator has separately addressed the planning basis for the implementation of wind power plants. The Act of 20 May 2016 on investments in wind power plants introduced (in Article 3) the principle that the location of wind power plants that are not micro-installations can only take place on the basis of local spatial development plans. Moreover, investments in wind turbines may be implemented at a certain distance from residential developments (residential buildings or buildings with mixed functions including residential functions). The minimum distance in this respect must be equal to ten times the height of the wind turbine. A local plan adopted for an investment specifying the location of a wind power plant must cover the entire area associated with the obligatory development restrictions.

The above solution is rigorous, especially in relation to the previous legal status. The said restriction is binding not only for the realization of an investment in the scope of a wind power plant, but also for the realization of residential buildings in a close proximity to the completed wind power plant (and on this occasion it applies not only to local plans, but also to decisions on development conditions). At the same time, it should be stressed that under the legal status before the enactment of the act in question, there were no top-down (statutorily imposed) limitations of this type (only the limitations of permissible noise levels for specific developments could be derived). As a result, power plants were built in too close proximity to buildings, especially residential buildings. 
A certain problem in the context of spatial policy is also the lack of differentiation of competencies of municipalities with respect to specific types of municipalities. This means that e.g., authorities of agricultural and urban communes have exactly the same spatial policy tools at their disposal. At the same time, the role of the powiat level in this context (a higher local government unit than municipalities) is negligible.

Planning securing the areas for functions related to the energy sector depends not only on the legal framework but also on the widely understood planning practice adopted in a given country. Planning coverage with applicable local plans means conscious planning for future use and securing land for investments of various activity profiles, including RES infrastructure facilities. In Poland, at the end of 2019, there were 55.6 thousand valid local plans and another 9.0 thous. were in the design process (including $54.6 \%$ of their area related to the existing plan change). The coverage was very uneven, both between regions (Figure 2) and in the types of communes (Table 2).

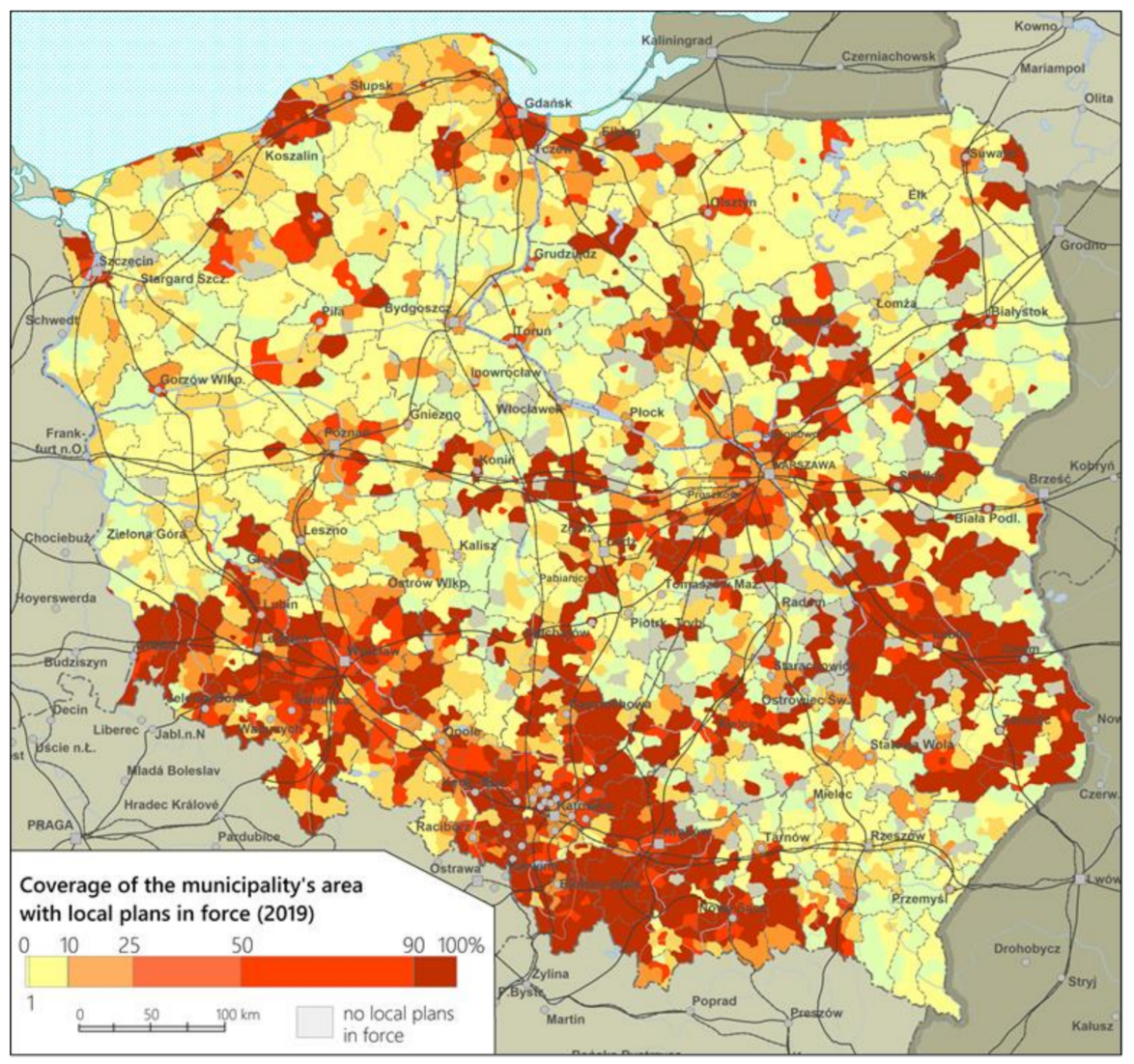

Figure 2. Planning coverage in Poland, for the year 2019. Source: based on data from the Ministry of Development and Central Statistical Office of Poland.

Table 2. Planning coverage by commune type and by population density, for the year 2019 .

\begin{tabular}{ccccc}
\hline \multirow{2}{*}{ Commune Type } & $\begin{array}{c}\text { Planing } \\
\text { Coverage (\%) }\end{array}$ & Including in Communes with Population Density \\
& Total & Below 50 & $\mathbf{5 0 - 1 5 0}$ & Above 150 \\
\cline { 2 - 5 } (Persons Per 1 sq. $\mathbf{~ k m ) ~}$ & (53.4 \\
\hline BD & 42.1 & 13.6 & 39.0 & 42.0 \\
\hline EFG & 29.9 & 21.4 & 36.5 & 58.0 \\
\hline HIJ & 28.1 & 23.6 & 33.1 & 54.0
\end{tabular}

Source: based on data from the Ministry of Development and Central Statistical Office of Poland. 
In general, in Poland, it is visible that the planning coverage is high in the south of the country: in the Dolnoślaskie, Śląskie and Małopolskie voivodeships, as well as in Lubelskie and partly Opolskie. In many communes of these regions, all communes or slightly less $(90 \%)$ are covered by local law's binding document. In other voivodeships, this indicator is high only in some areas, including agglomerations (coming from the north-Szczecin, Tri-City, Poznań, Łódź, Warsaw, Kielce).

At the other extreme, there is the northern part of the country, including its part of the lake district (especially the Zachodniopomorskie, Lubuskie, Kujawsko-Pomorskie and Warmińsko-Mazurskie voivodeships). In the south of the country, it is the Podkarpackie Province. The planning coverage indices there generally do not exceed $10 \%$ of the area of communes. In 146 communes in Poland (out of 2477 existing ones), in 2019, there was not a single local plan (e.g., concentrations of such communes are in Podlasie).

If the municipalities are grouped by population density (Table 2), it turns out that there is a clear relationship with the planning coverage. It is the lowest in sparsely populated communes (less than 50 people per $1 \mathrm{~km}^{2}$ ). The most disturbing fact is that the low coverage in this category of population density occurs in B and D types, i.e., suburban zones (only $13.6 \%)$. In general, coverage is also lower in typically rural areas (HIJ-28.1\%) and urban areas outside agglomerations (EGF-29.9\%). On the other hand, in the mentioned suburban zones (BD), the coverage is relatively high $(42.1 \%)$, though certainly too small relating to the needs resulting from intensive suburbanisation processes.

However, the planning coverage itself is not the only and exhaustive indicator that would assess the protection of areas for various functions. Next, Figure 3 and Table 3 show the share of the area intended for production functions in local plans, which should illustrate the protection of the areas for energy investments. In total, there were 403,000 ha such areas. On average, it was $1.29 \%$ of communes' area for the whole country, and again the least in the least populated areas $(0.68 \%)$. However, it is worth noting that such areas are anticipated in many municipalities where coverage is low (in northern Poland). But even there, these areas generally do not exceed $1 \%$ or even $0.2 \%$ of the communes' area.

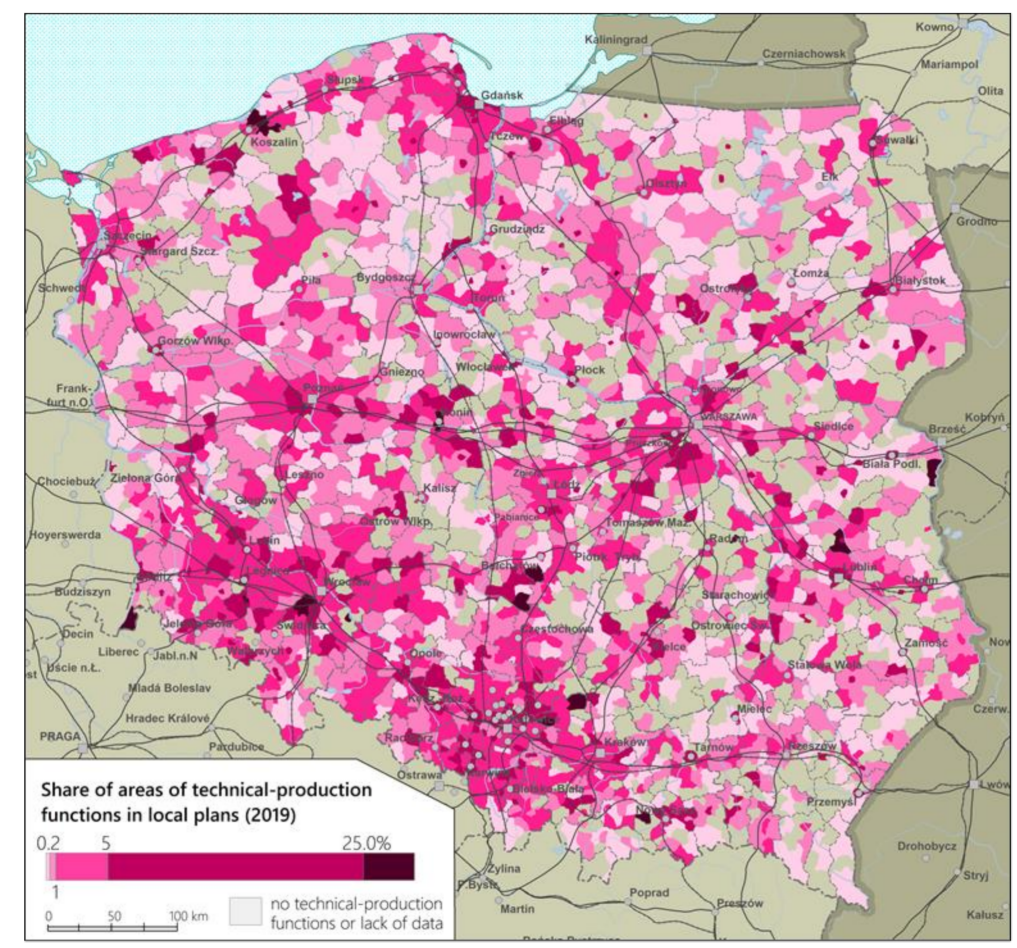

Figure 3. Share of the area of communes allocated to production functions in the spatial development local plans (local plans), for the year 2019 (relating to the area of communes). Source: based on data from the Ministry of Development and Central Statistical Office of Poland. 
Table 3. Share of the area of communes with the production function planned in the local plans, for the year 2019.

\begin{tabular}{ccccc}
\hline \multirow{2}{*}{ Commune Type } & $\begin{array}{c}\text { Planing } \\
\text { Coverage (\%) }\end{array}$ & \multicolumn{3}{c}{ Including in Communes with Population Density } \\
& Total & Below 50 & $\mathbf{5 0 - 1 5 0}$ & Above 150 \\
\cline { 2 - 5 } & 2.19 & 0.65 & 2.08 & 3.21 \\
\hline BD & 1.19 & 0.36 & 1.28 & 3.73 \\
\hline EFG & 0.93 & 0.77 & 1.04 & 3.34 \\
\hline HIJ & 1.29 & 0.68 & 1.32 & 3.79 \\
\hline
\end{tabular}

Source: based on data from the Ministry of Development and Central Statistical Office of Poland.

Besides, the documents of the study of the conditions and directions of spatial development for production functions provide for 592 thousand ha (data from 1687 communes for $68 \%$ of their number and $66 \%$ of the country's area). It is on average $2.9 \%$, the highest in urban types $\mathrm{A}$ and $\mathrm{C}(7.6-8.7 \%)$, and the lowest in types D, F, G and $\mathrm{H}$ (less than $3 \%$ ), including type $\mathrm{G}-1.2 \%$.

All in all, it should be acknowledged that the features resulting from the planning documents are not favourable for locating the energy sector in Poland. Securing the sites is only available in a smaller part of the country. Moreover, apart from the indicated data, one should bear in mind the varied content of planning provisions. As indicated above, the mere fact of a specific destination of the area does not constitute a guarantee that a given investment will be implemented quickly and without problems (judging only from the planning perspective). Barriers related to the Polish spatial management system (also the lack of sufficient flexibility in planning) will be noticeable also in the described context. More problems may arise when using a tool alternative to local plans, i.e., the decision on development conditions. One should also bear in mind the institutional limitations in implementing investments in wind farms implemented based on local plans.

\subsection{Settlement Conditions}

Poland's settlement structure's uniqueness results from the fact that it was shaped as a result of special historical influences, including significant shifts of borders in the 20th century. Regions of Poland's present-day territory developed basically independently of each other, which allowed for the emergence of large cities. After the Second World War, a large city system, known as polycentric, was finally formed. However, historical processes also had an overwhelming influence when it comes to small towns and rural settlements. The foundations of the rural settlement structure were formed as early as in the Middle Ages and under the influence of feudalism, which determined agrarian relations and the distribution and size of villages [57]. The agrarian relations were quite different in individual magnate states, and additionally, this was due to the different natural conditions. The situation in the nineteenth century had a significant impact. When the European countries were undergoing the industrial revolution and intensive urbanisation, Poland was a country divided among the partitioning states that pursued various policies in this regard.

Nowadays, in Poland, we can distinguish three partition zones (Russia, Prussia, Aussie) with differently advanced urbanisation processes, as well as historically industrialised (Silesia) and peripheral lands (Lubusz, Pomerania) of the German states. Two regularities follow from this. First, the area with the highest population density has the shape of a triangle, the base of which is the south of the country, and the peak is in the Tri-City. Secondly, there are different types of rural settlement in the country. The south is dominated by large and quite densely distributed villages, and in the north-small and rare (Figure 4). 


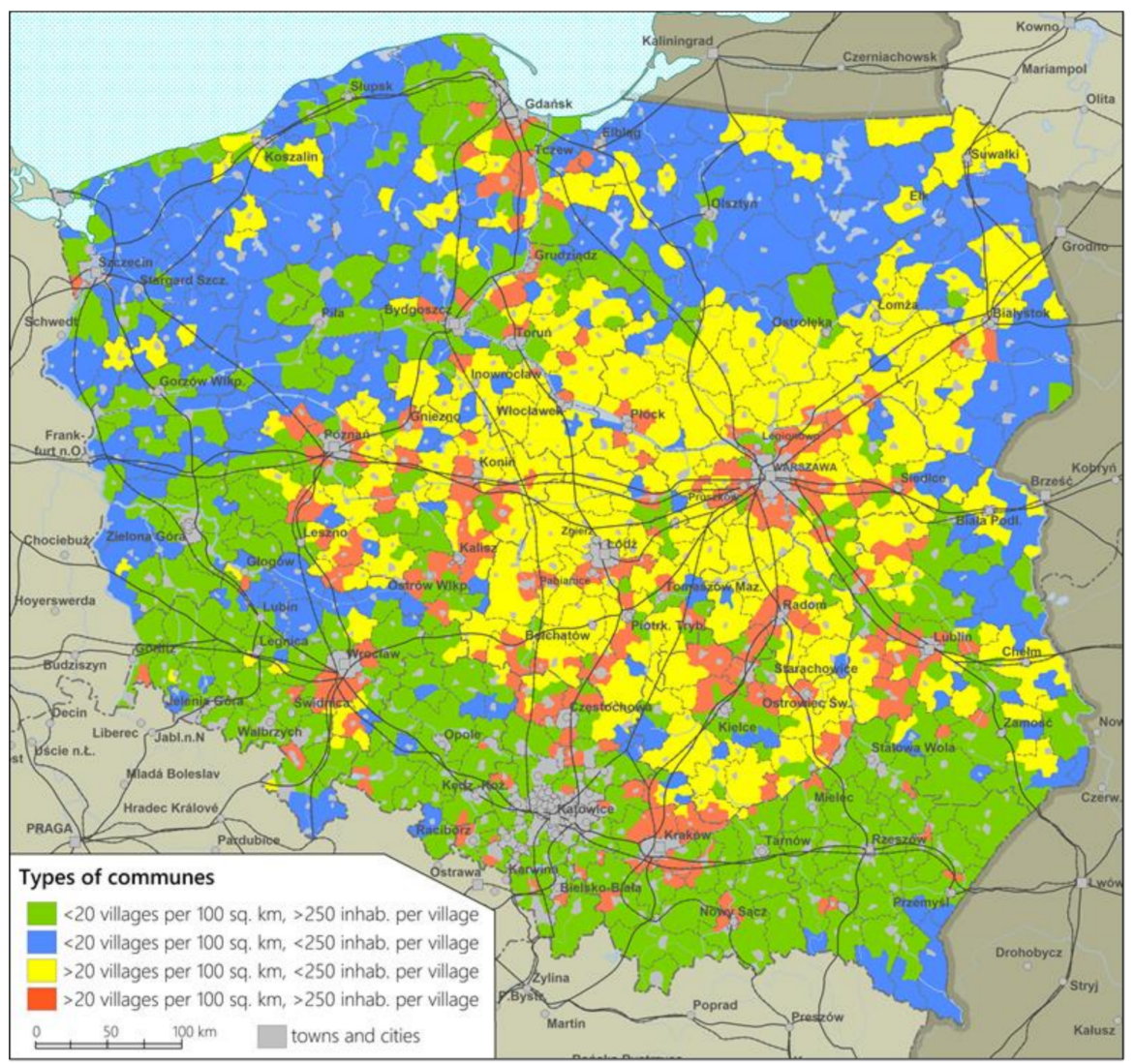

Figure 4. Typology of rural settlement in Poland in terms of village size and distribution, for the year 2019. Source: based on data of the Central Statistical Office of Poland.

In Poland, after around 1995, the process of centrifugal dispersion of buildings is progressing, and thus the deconcentration of settlement is part of the suburbanisation process $[70,71]$. Buildings "spread" far beyond the administrative borders of cities, as well as in many rural areas, especially attractive for tourists. However, it is not a simple "spreading" in Polish conditions, consisting of a gradual, relatively regular, centrifugal and elongated along the roads, occupying successive stretches of land, called "urban sprawl" in Western literature. In Poland, it consists of the chaotic induction of buildings in places that are often very distant from the previous settlement [72]. Between them, there are undeveloped, extensively developed spaces.

In total, the observed and growing dispersion of buildings and the deconcentration of settlement systems directly increase their functioning costs. It concerns three aspects resulting from lower population density and greater distances between places of residence, work, and services [10]:

- construction, modernisation, and maintenance costs of all line and point infrastructure,

- $\quad$ the costs of establishing relationships since places with different socio-economic functions are too far away,

- $\quad$ lower or no synergy effects and the so-called agglomeration benefits (scale).

The total costs of this are estimated at over PLN 80 billion per year.

The last data on the size structure of rural settlement in Poland comes from 2009. In this period, 41.7 thous. villages (Table 4). The vast majority of the rural population was concentrated in medium and large villages (101-3.333 inhabitants-90.2\%). On the other hand, the number of villages up to 100 inhabitants was relatively large (22.1\%), but they concentrated only $3.7 \%$ of the rural population. The share of villages with such a few inhabitants was characteristic, especially in the country's north-east (Figure 5). 
Table 4. Size structure of villages in Poland, for the year 2009.

\begin{tabular}{ccccc}
\hline Size & $\begin{array}{c}\text { Number of } \\
\text { Villages }\end{array}$ & $\begin{array}{c}\text { Share of } \\
\text { Number (\%) }\end{array}$ & $\begin{array}{c}\text { Number of } \\
\text { Population (thous.) }\end{array}$ & $\begin{array}{c}\text { Share of } \\
\text { Population (\%) }\end{array}$ \\
\hline$<33$ & 1450 & 3.5 & 22 & 0.1 \\
\hline $34-100$ & 7751 & 18.6 & 537 & 3.6 \\
\hline $101-333$ & 19,499 & 46.8 & 3822 & 25.4 \\
\hline $334-1000$ & 10,168 & 24.4 & 5575 & 37.0 \\
\hline $1001-3333$ & 2587 & 6.2 & 4178 & 27.7 \\
\hline$>3333$ & 204 & 0.5 & 939 & 6.2 \\
\hline Total & 41,659 & 100.0 & 15,073 & 100.0 \\
\hline
\end{tabular}

Source: based on Central Statistical Office of Poland data.

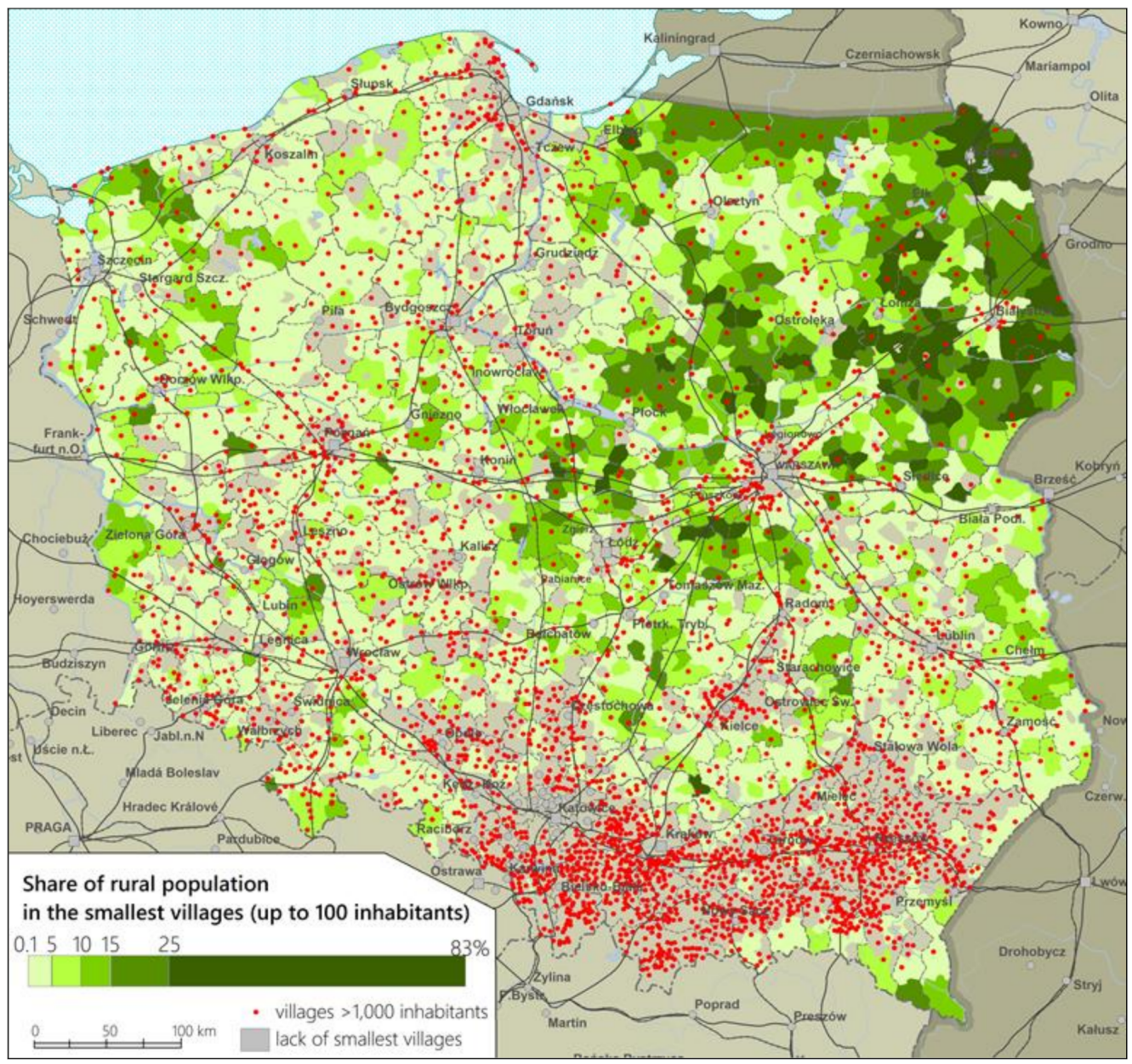

Figure 5. Share of the rural population in the smallest villages (up to 100 inhabitants). Source: based on Central Statistical Office of Poland data.

Moreover, there were very few large villages (over 1000 inhabitants) in this area. It is worth noting that this is a region with a high value for the natural environment, not accidentally known as the "Green Lungs of Poland" [73]. Hence, the use of RES-based distributed generation seems to have particularly strong foundations there.

\section{Discussion}

The described issues are part of settlement efficiency's fundamental problem and the optimal degree of concentration of various functions and activities. In this respect, energy 
production, distribution, and consumption are not yet satisfactorily identified and certainly require further research [74]. Even in very sparsely populated countries, the geographic and settlement conditions for the development of distributed energy are practically not discussed [75]. Meanwhile, the low efficiency of settlement systems in rural areas causes a reduction in "functional efficiency" and the ineffectiveness of traditional energy supply methods [76]. Examples of studies from Poland using the Minimum Spanning Tree (MST) methodology show that the indicators of the efficiency and effectiveness of the technical and settlement network in rural areas differ even ten times [77]. It creates enormous potential for more rational planning of energy systems (electric, heating). It seems that in the light of the empirical analyses in the previous section, this has been well documented.

In scattered development areas, the infrastructure network's length per person (per household) must be longer and thus more expensive. This is the case of Poland [58]. Hence, many rural areas of Poland have unfavourable conditions for the development of traditional linear infrastructure but favourable for the development of distributed generation. It is especially true of the northern part of the country, where the settlements are far apart, and the villages are small.

On the other hand, it is worth pointing to the south of the country. The problem of low emissions from traditional coal and wood-fired heating boilers is related to specific natural conditions in mountain valleys and land depression, very unfavourably exposed to smog [78]. Due to Poland's size, the importance of these issues is very great and may bring important conclusions for planning energy systems in other countries. The analysis of the contents in local spatial development plans shows that the problem may be securing land for energy infrastructure in many areas of the country.

In the context of the spatial management system's conditions, it is worth paying attention to several issues. First, the way of presenting the tools of spatial policy determines the effectiveness of the implementation of energy investments. In Poland's case, both the indeterminacy of a significant part of local spatial development plans and the unclear statutory provisions relating to development conditions' decisions determine the extension and actual blocking of this type of investment. The dependence of the clarity of planning regulations and the efficiency of energy investments implementation requires examination in other countries with different regulations and different planning practices [75]. To a limited extent, it may be a factor that determines the development of the energy sector, noticeable so far in the literature on the subject.

The issue of spatial conflicts that arise during the implementation of larger energy investments in wind farms is also important [79]. In the first place, they relate to the protection of the cultural landscape and possible collisions with the housing function. There is a discussion on how significantly different considerations regarding the protection of the cultural landscape may limit the possibilities of development (and implementation of energy investments) in the legal sphere [80]. The authors believe that this scope should be wide, and detailed analyses should be reflected as broadly as possible in legal and planning regulations (which must be considered when determining the scale and investment opportunities in the field of energy). Moreover, it can be indicated that some publications also differentiate the impact of individual RES on the environment $[36,37,81]$. Therefore, there is no doubt that the spatial policy perspective should balance the indicated problems and interests.

Changes in the spatial policy should contribute to solving these problems. On the one hand, it is related to the demand to specify the scope of environmental, nature and landscape protection in the Polish spatial management system. At present, the terminological diversity is too wide (also in law), which generates spatial conflicts to an even greater extent. The role of local municipal authorities seems to be important; through their own analyses, they should define threats to environment, nature and landscape much better than it is now. Better definition of threats will make it easier to correlate spatial policy with the goal of implementing RES investments. This problem is important in the context 
that, as shown in the Results section, the planning coverage is particularly low in areas especially predestined for renewable energy development (northern and eastern Poland).

Another sphere of significant conflicts concerns housing development. Firstly, residents' protests may lead to limitations in implementing investments, even if the formal framework theoretically does not prevent it. Hence, in this context, the postulate of deepening social participation in the development policy, including spatial planning, also seems to be right. No such blockages appear at the implementation stage [81]. It should also be remembered that these investments play an important role in improving the inhabitants' quality of life. Secondly, after 2016 large investments in wind farms are subject to significant restrictions in the development of neighbouring areas in the Polish reality. Determining the possibility of implementing such an investment in local plans is equivalent to prohibiting development around it. Especially in the case of scattered development, it may cause accusations of blocking the residential function's development. These dilemmas are interesting, especially in the context of signalling in the literature on the need to reconcile diffused energy facilities' location and operation with other purposes related to land use [82]. It makes it even more important to reconcile individual expectations when developing rural areas [30].

The above circumstance leads to the deepening of barriers in implementing investments in the field of large wind farms-even because it is often difficult to find an area that would meet all distance requirements. Thus, another dilemma is noticeable on this occasion: balancing the relationship between the scope of protection of residential areas and the effective implementation of investments in the field of wind farms. There will be much fewer problems in determining the planning foundations for implementing microinstallations (including distributed energy). Of course, the barriers mentioned above to the possible ambiguity of post-planning and ambiguities related to the interpretation of regulations related to spatial development appear on this occasion. Nevertheless, the implementation of this type of investment does not face such barriers as those resulting from the act on investments in wind farms (without causing any damage related to the exploitation of non-renewable energy sources).

Poland's case also shows how the framework related to the local spatial policy can be a derivative of specific administrative-political decisions. This issue is all the more important because local authorities' role in energy policy is strongly emphasised in the literature [83]. Based on the conducted research, it is possible to confirm the importance of local authorities in this respect $[47,48]$ and the validity of further expectations towards the authorities [50]. In the Polish spatial management system, the change allowing for a much wider inclusion of micro-installations in local plans entered into force in 2016 (previously, micro-installations were associated only with the production purpose of the area, and a significant part of the jurisprudence indicated that they must be directly provided for in the plan). The change resulted from both the discussion on the importance of renewable energy sources for individual countries and the European Union's examples and recommendations. Thanks to this, it is possible to implement micro-installations not only in areas with assigned production purposes.

However, it should be emphasised that the interpretation dilemmas in the Polish spatial management system are related to entirely formal and legal issues. Both the problems with the interpretation of local plans and the different qualifications of micro-installations in the context of the decision on land development and development conditions do not lead to better land development (or even to a discussion in this respect), but to the problems related to the interpretation of the regulations that obscure this context. It requires correction, especially when recalling the European Parliament's recommendations regarding the transparency of administrative procedures related to a certain freedom of action by planning bodies. Wider use of soft (e.g., informal) spatial policy tools could be helpful here.

The case of Poland confirms that the quality of specific spatial policy tools and the related quality of spatial policies themselves significantly affects the implementation of other sectoral objectives. This is the case of RES investments. Problems related to the 
interpretation of local plans or conditions for issuing decisions on development conditions can often prolong or block the implementation of specific investments. In the long-term perspective, they may even determine the very concept regarding the scope of RES investments. This is why it seems so important to improve the current factual and legal situation in Poland. The necessity of broadening and adapting the analyses of spatial determinants to different levels of spatial policies has been already indicated [84].

Improving the quality of these analyses and adapting them to the local spatial policies is very important. It also seems important to ensure (at a later, implementation stage) some flexibility in planning. This should include at least some of the investments. The scheme would be such that the spatial policy tools based on the spatial development analyses would create certain frameworks, which would be specified in detail at the implementation stage (a similar principle is based on e.g., the British spatial planning model) [85-87].

In the context of the discussion on the integrated model of development planning, it is worth pointing to the need for a more coordinated energy policy and spatial policy integration. It can be reflected in integrated energy plans that consider spatial conditions. The recommendations contained in the 2030 Territorial Agenda can be a particular inspiration here. The more so as it is addressed to various stakeholders (not only the central level of individual countries) [88]. The specific conditions and potentials of individual countries, indicated in the literature review as the basic point of reference for energy policy issues, perfectly correspond to development policies' focus on specific places promoted in the Agenda.

The implementation of the Agenda 2030 guidelines may pose interesting challenges, also for local spatial policies [89]. Agenda 2030 defines the key directions, but its advantage is that it leaves a lot of flexibility for specific public authorities. The place-based policy proposals contained in the Agenda can therefore be applied holistically to the case of Poland (and its settlement specificity in the context of RES investment opportunities), as well as its specific areas. The concept of expanding RES investments should also be correlated with the concept of "Green Europe" included in the Agenda. While discussing public policies, it is also worth noting in passing that the COVID-19 pandemic is an opportunity to redefine many aspects of these policies [90]. It also provides a basis for developing new approaches to public policy tools. Adaptation of spatial policy tools to the indicated postulates is also fully in line with these trends.

To conclude the discussion, it is still worth noting the problem of locating renewable and distributed energy systems in the context of the social situation, including energy exclusion [91]. Other studies show that sparsely populated areas in Poland with dispersed settlement are also problem areas [92], subject to economic stagnation and depopulation. Meanwhile, the implementation of renewable energy for single households is most often associated with serious unit costs at the beginning of the investment. This requires a particularly skillful development policy at the local level, but also regional and national support programs in the form of an offer of economic instruments (e.g., subsidies). This is all the more so as the first studies from Poland indicate a widening of energy poverty due to the COVID-19 pandemic [34].

\section{Conclusions}

Answering the research questions posed in the introduction, based on the analyses performed, it can be indicated that dispersed development in Poland is a factor favourable for the development of a RES-based distributed generation. Its implementation, especially with the domination of non-renewable energy sources, is associated with limiting potential spatial conflicts. It is also confirmed by a relatively smaller number of spatial conflicts regarding implementing these investments (especially if we refer to wider problems of the spatial management system). Planning doubts and ambiguities do occur, of course, but on a much smaller scale. Anyway, the direction of reducing these ambiguities should be a wider adaptation of local spatial policy tools to the types of renewable energy sources (e.g., 
wind, solar, water). Consideration should also be given to allow for smaller power plants, particularly biomass power plants, to be located in residential areas.

The above conclusions confirm the thesis about the high homogeneousness of the Polish law of spatial development. The diagnosed barriers constitute the basis for confirming that the legal regulations do not consider the needs related to the differentiation of the applicable guidelines and their adaptation to the diverse settlement structure. Problems regarding the classification of micro-installations as public purpose investments and technical infrastructure devices confirm the thesis that in the Polish spatial management system, overly detailed, formal and legal perception of individual solutions contributes to artificial dilemmas, introducing unnecessary barriers and difficulties. Additionally, this formal and legal approach does not bring the expected results to prevent spatial conflicts. In this context, key directions for changes can be recommended. First, they should reduce to covering larger areas (constituting a whole in terms of functionality) with local plans. Such local plans should consider the guidelines related to integrated development planning, i.e., their decisions should be based on broader analyses, considering the context and needs of energy policy (the more so as it should also be different for individual areas). The direction limiting the detail of planning regulations (and the related non-substantive dilemmas) may be at least a partial introduction of flexibility in planning (based on the British spatial management system). It is also connected with broadening the scope of application of soft (e.g., informal) tools of spatial policy.

Based on the analyses carried out, the following recommendations can be made for spatial policies:

- $\quad$ expanding the role of analyses in spatial management-first of all on a local scale (a postulate both to local authorities and national authorities responsible for the entire spatial management system);

- $\quad$ wider correlation between the conditions for RES investments and the requirements of environmental, nature and landscape protection (both to the local authorities and national authorities);

- Clarification of the scope of local spatial policy tools and the introduction of greater flexibility at the implementation stage (demand to national authorities);

Include these proposals in the context of discussions on changes in public policy caused by the COVID-19 pandemic (request to local and national authorities), also in relation to the problem of energy exclusion.

It should also be emphasised that there is potential for further research. Such studies should specify which of the DG/RES types would be the most optimal from the point of view of efficiency and rationality for different areas. As has been shown, the northeastern part of Poland is an area with a particularly large share of small villages (less than 100 inhabitants). In comparison, there are many large villages in the southern part of the country (more than 1000 inhabitants). This type of analysis should also be included in the formal and legal framework defining the spatial management system's principles, differentiated by territory. Other directions for further research should address:

- comparison of barriers when applying spatial policy tools in different countries;

- ways of solving spatial conflicts when determining the location and implementation of RES (including distributed renewable energy production) in different countries;

- $\quad$ public participation in RES planning and implementation process. There is no doubt that dispersed development can be a significant stimulator of distributed renewable energy production. For this to be possible, it seems of key importance to modify the current spatial policy tools, first to the extent that will guarantee a wider than currently differentiation of the conditions for the development of individual areas.

For the reasons mentioned above, it can be concluded that the securing of land for the energy-related functions by communes is insufficient. The implementation of most large wind farms in many places is indeed blocked or very difficult. Regarding distributed energy, within the framework of spatial policy tools, some grounds for further actions and 
facilitation can be found. However, procedural barriers (related to the interpretation of detailed provisions) are often serious obstacle.

Conclusions from the presented research for Poland are also crucial for other countries or will undergo energy transformation. The use of distributed renewable energy may prove particularly useful in peripheral and depopulating regions (the Iberian Peninsula, southern Italy, Central and Eastern Europe).

Author Contributions: P.Ś. and M.N. and A.B.; methodology, P.Ś., M.N.; software, P.Ś. and N.O.; validation, N.O. and M.N.; formal analysis, P.Ś., M.N., A.B.; investigation, P.Ś., M.N., A.B. and B.M.; resources, P.Ś. data curation, P.Ś.; writing—original draft preparation, P.Ś., M.N., A.B., B.M.; writingreview and editing, M.N., P.Ś. and A.B.; visualization, P.Ś. and N.O.; supervision, M.N.jproject administration, M.N.; funding acquisition, B.M. All authors have read and agreed to the published version of the manuscript.

Funding: This research received no external funding.

Institutional Review Board Statement: Not applicable.

Informed Consent Statement: Not applicable.

Data Availability Statement: Please refer to suggested Data Availability Statements in section “MDPI Research Data Policies" at https:/ /www.mdpi.com/ethics, accessed on 30 March 2021.

Conflicts of Interest: The authors declare no conflict of interest.

\section{References}

1. Szelenyi, I.; Beckett, K.; King, L.P. The socialist economic system. In The Handbook of Economic Sociology; Smelser, N.J., Swedberg, R., Eds.; Princeton University Press: New York, NY, USA, 1994; pp. 234-251.

2. Wẹclawowicz, G. Contemporary Poland: Space and Society; UCL Press: London, UK, 1996.

3. Ackermann, T.; Andersson, G.; Söder, L. Distributed generation: A definition. Electr. Power Syst. Res. 2001, 57, 195-204. [CrossRef]

4. Rezolucja Zgromadzenia Ogólnego A/RES/70/1 z dnia 25 Września 2015 r. (bez Odniesienia do Komitetu Głównego (A/70/L.1)). Agenda na Rzecz Zrównoważonego Rozwoju 2030. Available online: https:/ / www.un.org.pl/agenda-2030-rezolucja (accessed on 29 March 2021).

5. Directive (EU) 2018/2001 of the European Parliament and of the Council of 11 December 2018 on the Promotion of the Use of Energy from Renewable Sources (Text with EEA Relevance.). Available online: https:/ / eur-lex.europa.eu/eli/dir/2018/2001/oj (accessed on 1 March 2021).

6. Komornicki, T.; Szejgiec-Kolenda, B.; Degórska, B.; Goch, K.; Śleszyński, P.; Bednarek-Szczepańska, M.; Siłka, P. Spatial planning determinants of cohesion policy implementation in Polish regions. Europa 2018, 21, 69-87. [CrossRef]

7. Nadin, V.; Fernández Maldonado, A.; Zonneveld, W.; Stead, D.; Dabrowski, M.; Piskorek, K.; Sarkar, A.; Schmitt, P.; Smas, L.; Cotella, G.; et al. COMPASS-Comparative Analysis of Territorial Governance and Spatial Planning Systems in Europe Applied Research 2016-2018 Final Report; ESPON: Luxembourg, 2018; Available online: https:/ /www.espon.eu/planning-systems (accessed on 10 December 2020).

8. Rosner, A.; Wesołowska, M. Deagrarianisation of the Economic Structure and the Evolution of Rural Settlement Patterns in Poland. Land 2020, 9, 523. [CrossRef]

9. Stasiak, A. Changes in rural settlement in Poland up to 2000. Geogr. Pol. 1989, 56, 109-114.

10. Śleszyński, P.; Kowalewski, A.; Markowski, T.; Legutko-Kobus, P.; Nowak, M. The contemporary economic costs of spatial chaos: Evidence from Poland. Land 2020, 9, 214. [CrossRef]

11. Florida, R. The Geography of Coronavirus, City Lab, 3.04.2020. Available online: https://www.bloomberg.com/news/articles/ 2020-04-03/what-we-know-about-density-and-covid-19-s-spread (accessed on 13 March 2020).

12. Komornicki, T. Spatial planning in Poland the territorial perspective. In Territorio y Estados: Elementos para la Coordinación de las Políticas de Ordenación del Territorio en el Siglo XXI; Tirant lo Blanch: Valencia, Spain, 2018; pp. 529-562, ISBN 9788416556854.

13. Lityński, P.; Hołuj, A. Urban Sprawl Risk Delimitation: The Concept for Spatial Planning Policy in Poland. Sustainability 2020, 12, 2637. [CrossRef]

14. Kaczmarek, T.; Mikuła, Ł. The Housing Market in Poland in the Liberalized Spatial Planning System: The National Context and Metropolitan Dimension of the Poznań Agglomeration. In Housing and Housing Politics in European Metropolises. Jahrbuch Stadtregion; Wehrhahn, R., Pohlan, J., Hannemann, C., Othengrafen, F., Schmidt-Lauber, B., Eds.; Springer: Wiesbaden, Germany, 2019. [CrossRef]

15. Aguirre, M.; Ibikunle, G. Determinants of renewable energy growth: A global sample analysis. Energy Policy 2014, 69, 374-384. [CrossRef]

16. Burke, M.J.; Stephens, J.C. Political power and renewable energy futures: A critical review. Energy Res. Soc. Sci. 2018, 35, 78-93. [CrossRef] 
17. Sareen, S. Energy distribution trajectories in two Western Indian states: Comparative politics and sectoral dynamics. Energy Res. Soc. Sci. 2018, 35, 17-27. [CrossRef]

18. Zawalińska, K.; Kinnunen, J.; Gradziuk, P.; Celińska-Janowicz, D. To Whom Should We Grant a Power Plant? Economic Effects of Investment in Nuclear Energy in Poland. Energies 2020, 13, 2687. [CrossRef]

19. Gielen, D.; Boshell, F.; Saygin, D.; Bazilian, M.D.; Wagner, N.; Gorini, R. The role of renewable energy in the global energy transformation. Energy Strategy Rev. 2019, 24, 38-50. [CrossRef]

20. Ioannou, K.; Tsantopoulos, G.; Arabatzis, G.; Andreopoulou, Z.; Zafeiriou, E.A. Spatial Decision Support System Framework for the Evaluation of Biomass Energy Production Locations: Case Study in the Regional Unit of Drama, Greece. Sustainability 2018, 10, 531. [CrossRef]

21. Lazaroiu, G.; Mihaescul, L.; Jarcu, E.A.; Stanescu, L.A.; Ciupageanu, D.A. Renewable energy employment in Romania: An environmental impact discussion. In Proceedings of the International Multidisciplinary Scientific GeoConference: SGEM, Albena, Bulgaria, 18-24 August 2020; Volume 20, pp. 177-184. Available online: https://www.sgem.org/index.php/elibrary?view= publication\&task=show\&id=7229 (accessed on 29 March 2021).

22. Barragán-Escandón, A.; Terrados-Cepeda, J.; Zalamea-León, E. The Role of Renewable Energy in the Promotion of Circular Urban Metabolism. Sustainability 2017, 9, 2341. [CrossRef]

23. Zhao, P.; Fang, J.; Paramati, S.R.; Jiang, K. Determinants of renewable and non-renewable energy demand in China. Struct. Chang. Econ. Dyn. 2020, 54, 202-209. [CrossRef]

24. Alvarez-Herranz, A.; Balsalobre-Lorente, D.; Shahbaz, M.; Cantos, J.M. Energy innovation and renewable energy consumption in the correction of air pollution levels. Energy Policy 2017, 105, 386-397. [CrossRef]

25. Johnstone, N.; Haščič, I.; Popp, D. Renewable Energy Policies and Technological Innovation: Evidence Based on Patent Counts. Environ. Resour. Econ. 2010, 45, 133-155. [CrossRef]

26. Dogru, T.; Bulut, U.; Kocak, E.; Isik, C.; Suess, C.; Sirakaya-Turk, E. The nexus between tourism, economic growth, renewable energy consumption, and carbon dioxide emissions: Contemporary evidence from OECD countries. Environ. Sci. Pollut. Res. Int. 2020, 27, 40930-40948. [CrossRef]

27. Gan, L.; Eskeland, G.S.; Kolshus, H.H. Green electricity market development: Lessons from Europe and the US. Energy Policy 2007, 35, 144-155. [CrossRef]

28. UNIDO. Global Value Chains and Industrial Development: Lessons from China, South-East and South Asia; UNIDO: Vienna, Austria, 2018. Available online: https:/ / www.unido.org/sites/default/files/files/2018-06/EBOOK_GVC.pdf (accessed on 29 March 2021).

29. Mata, T.M.; Martins, A.A.; Sikdar, S.K.; Costa, C.A.V.; Caetano, N.S. Sustainability analysis of biofuels through the supply chain using indicators. Sustain. Energy Technol. Assess. 2013, 3, 53-60. [CrossRef]

30. Garcia-Casals, X.; Ferroukhi, R.; Parajuli, B. Measuring the socio-economic footprint of the energy transition. Energy Transit. 2019, 3, 105-118. [CrossRef]

31. Mainali, B. Sustainability of Rural Energy Access in Developing Countries. Ph.D. Thesis, Royal Institute of Technology-KTH, Stockholm, Sweden, 2014.

32. Waldenström, C.; Ferguson, R.; Sundberg, C.; Tidåker, P.; Westholm, E.; Åkersko, A. Bioenergy from agriculture: Challenges for the rural development program in Sweden. Soc. Nat. Resour. 2016, 29, 1467-1482. [CrossRef]

33. Dai, H.; Xuxuan, X.; Xie, Y.; Liu, J.; Masui, T. Green growth: The economic impacts of large-scale renewable energy development in China. Appl. Energy 2016, 162, 435-449. [CrossRef]

34. Nagaj, R.; Korpysa, J. Impact of COVID-19 on the Level of Energy Poverty in Poland. Energies 2020, 13, 4977. [CrossRef]

35. Chiradeja, P.; Ramakumar, R. An approach to quantify the technical benefis of distributed generation. IEEE Trans. Energy Convers. 2004, 19, 764-773. [CrossRef]

36. Ackerman, A.S.; Toon, O.B.; Taylor, J.P.; Johnson, D.W.; Hobbs, P.V.; Ferek, R.J. Effects of aerosols on cloud albedo: Evaluation of Twomey's parameterisation of cloud susceptibility using measurements of ship tracks. J. Atmos. Sci. 2000, 57, 2684-2695. [CrossRef]

37. Willis, H.L.; Scott, W.G. Distributed Power Generation. Planning and Evaluation; CRC Press: New York, NY, USA, 2018.

38. Rae, C.; Kerr, S.; Maroto-Valer, M.M. Upscaling smart local energy systems: A review of technical barriers. Renew. Sustain. Energy Rev. 2020, 131, 110020. [CrossRef]

39. Dugan, R.C.; McDermott, T.E.; Ball, G.J. Planning for distributed generation. IEEE Ind. Appl. Mag. 2001, 7, 80-88. [CrossRef]

40. Lewandowska, A.; Chodkowska-Miszczuk, J.; Rogatka, K. Development of renewable energy sources in big cities in Poland in the context of urban policy. In Renewable Energy Sources: Engineering, Technology, Innovation; Springer: Cham, Switzerland, 2020.

41. Herran, D.S.; Nakata, T. Design of decentralised energy systems for rural electrification in developing countries considering regional disparity. Appl. Energy 2012, 91, 130-145. [CrossRef]

42. Agarwal, U.; Jain, N. Distributed Energy Resources and Supportive Methodologies for their Optimal Planning under Modern Distribution Network. Technol. Econ. Smart Grids Sustain. Energy 2019, 4, 3. [CrossRef]

43. Koirala, B.P.; Koliou, E.; Friege, J.; Hakvoort, R.A.; Herder, P.M. Energetic communities for community energy: A review of key issues and trends shaping integrated community energy systems. Renew. Sustain. Energy Rev. 2016, 56, 722-744. [CrossRef]

44. Longo, M.; Roscia, M.; Lazaroiu, G.C.; Pagano, M. Analysis of Sustainable and Competitive Energy System. Available online: https:/ / ieeexplore.ieee.org/abstract/document/7016516 (accessed on 29 March 2021). 
45. Kabuth, A.; Dahmke, A.; Beyer, C.; Bilke, L.; Dethlefsen, F.; Dietrich, P.; Duttmann, R.; Ebert, M.; Feeser, V.; Görke, U.J.; et al. Energy storage in the geological subsurface: Dimensioning, risk analysis and spatial planning: The ANGUS+ project. Environ. Earth Sci. 2017, 76, 23. [CrossRef]

46. Lund, H.; Duić, N.; Krajac `ić, G.; da Graça Carvalho, M. Two energy system analysis models: A comparison of methodologies and results. Energy 2007, 32, 948-954. [CrossRef]

47. Szyrski, M. Rola Samorzadu Terytorialnego w Rozwoju Odnawialnych Źródet Energii (OZE). Analiza Administracyjnoprawna; Wolters Kluwer: Worsaw, Poland, 2017.

48. Meschede, H.; Child, M.; Breyer, C. Assessment of sustainable energy system configuration for a small Canary island in 2030. Energy Convers. Manag. 2018, 165, 363-372. [CrossRef]

49. Dorotić, H.; Doračić, B.; Dobravec, V.; Pukšec, T.; Krajačić, G.; Duić, N. Integration of transport and energy sectors in island communities with 100\% intermittent renewable energy sources. Renew. Sustain. Energy Rev. 2019, 99, 109-124. [CrossRef]

50. Gawlik, L. The Polish power industry in energy transformation process. Miner. Econ. 2018, 31, 229-237. [CrossRef]

51. Asensio, C.; Lozano, F.J.; Ortega, E.; Kikvidze, Z. Study on the effectiveness of an agricultural technique based on aeolian deposition, in a semiarid environment. Environ. Eng. Manag. J. 2015, 14, 1143-1150. [CrossRef]

52. Lazaroiu, G.; Ciupageanu, D.A.; Vatuiu, T. Highlights of renewable energy integration impact: Evolution and perspectives in Romania. In Proceedings of the 21st International Symposium on Electrical Apparatus \& Technologies (SIELA), Bourgas, Bulgaria, 3-6 June 2020.

53. Lu, Y.; Khan, Z.A.; Alvarez-Alvarado, M.S.; Zhang, Y.; Huang, Z.; Imran, M. A Critical Review of Sustainable Energy Policies for the Promotion of Renewable Energy Sources. Sustainability 2020, 12, 5078. [CrossRef]

54. Ferrer, J.N.; Cătuţi, M.; Stroia, C.; Bryhn, J. Comparative Study on the Governance Structure and Energy Policies in EU Macro-Regional Strategies; Research Report; Thinking Ahead for Europe; CEPS: Brussels, Belgium, 2019; p. 2.

55. Alper, A.; Oguz, O. The role of renewable Energy consumption in economic growth: Evidence from assymetric causality. Renew. Sustain. Energy Rev. 2016, 60, 953-959. [CrossRef]

56. Łaczak, A.; Bazan-Krzywoszańska, A.; Mrówczyńska, M.; Skiba, M. Renewable Energy Sources in the Lubusz Voivodship (Poland). The Present Conditions and Perspectives for Development. Civ. Environ. Eng. Rep. 2018, 28, 31-67. [CrossRef]

57. Szulc, H. Historical geography of rural settlement in Poland. In Geographie Historique et Culturelle de l'Europe: Hommage au Professeur Xavier de Planhol; Pitte, J.R., de Planhol, X., Eds.; Presses de l'Université de Paris-Sorbonne: Paris, France, 1995; pp. $381-393$.

58. Heffner, K.; Gibas, P. Centra regionów a spójność regionalna w Polsce. Res. Pap. Wrocław Univ. Econ. 2017, 466, 98-110.

59. Śleszyński, P.; Komornicki, T. Functional classification of Poland's communes (gminas) for the needs of the monitoring of spatial planning [Klasyfikacja funkcjonalna gmin Polski na potrzeby monitoringu planowania przestrzennego]. Przegląd Geogr. 2016, 88, 469-488. [CrossRef]

60. Nowak, M. The Role and Effects of Case-Low in Spatial Competition. An analysis of selected cases. Biul. Kom. Przestrz. Zagospod. Kraj. PAN 2017, 265, 172-180.

61. Karwińska, A.; Böhm, A.; Kudłacz, M. The phenomenon of urban sprawl in modern Poland: Causes, effects and remedies. Zarzadzanie Publiczne/Public Gov. 2018, 3, 26-43. [CrossRef]

62. Lorens, P. Trends and problems of contemporary urbanisation processes in Poland. In Spatial Planning and Urban Development in the New EU Member States; Altrock, U., Ed.; Routledge: Abingdon, UK, 2017; pp. 109-126. Available online: https: / / www.routledge.com/Spatial-Planning-and-Urban-Development-in-the-New-EU-Member-States-From/AltrockGuntner-Peters/p/book/9780754646846 (accessed on 22 April 2017).

63. Izdebski, W.; Śleszyński, P.; Malinowski, Z.; Kursa, M. Analiza morfometryczna planów miejscowych w Polsce. Infrastrukt. i Ekol. Teren. Wiej. 2018, 2, 331-347. [CrossRef]

64. Mickiewicz, P.; Nowak, M. Environmental protection and integrated development planning in local spatial policy on the example of Poland. Ann. Univ. Apulensis Ser. Oecon. 2020, 22, 11-18. [CrossRef]

65. Śleszyński, P.; Nowak, M.; Sudra, P.; Załęczna, M.; Blaszke, M. Economic Consequences of Adopting Local Spatial Development Plans for the Spatial Management System: The Case of Poland. Land 2021, 10, 112. [CrossRef]

66. Parysek, J.J. Asking about the future of spatial management in Poland (thirteen years on from the 2003 legal regulation). Ruch Praw. Ekon. I Socjol. 2016, 78, 37-58. [CrossRef]

67. Cotella, G. Spatial planning in Poland between European influence and dominant market forces. In Spatial Planning Systems and Practices in Europe. A Comparative Perspective on Continuity and Changes; Reimer, M., Getimis, P., Blotevogel, H., Eds.; Routledge: New York, NY, USA, 2014.

68. Nowak, M. The Statekholders and Municipal Authorities in the Spatial Competition. Biul. Kom. Przestrz. Zagospod. Kraj. PAN 2017, 265, 22-35.

69. Nawrot, F. Budowa instalacji odnawialnych źródeł energii a planowanie przestrzenne. Prawne Probl. Górnictwa I Ochr. Środowiska 2017, 1, 71-89.

70. Biegańska, J.; Szymańska, D. The scale and the dynamics of permanent migration in rural and peri-urban areas in Poland-Some problems. Bull. Geogr. Socio-Econ. Ser. 2013, 21, 21-30. [CrossRef]

71. Gałka, J.; Warych-Juras, A. Suburbanization and migration in polish metropolitan areas during political transition. Acta Geogr. Slov. 2018, 58, 64-72. [CrossRef]

72. Gutry-Korycka, M. (Ed.) Urban Sprawl; Warsaw Agglomeration Case Study; Warsaw Uniwersity Press: Warsaw, Poland, 2005. 
73. Stanny, M.; Czarnecki, A. Level and determinants of sustainable rural development in the Region of Green Lungs of Poland. Rural Areas Dev. 2010, 7, 197-212. [CrossRef]

74. Sharma, D.; Bartels, R. Distributed Electricity Generation in Competitive Energy Markets: A Case Study in Australia, International Association for Energy Economics. Energy J. 1997, 18. [CrossRef]

75. Miskinis, V.; Norvaisa, E.; Galinis, A.; Konstantinaviciute, I. Trends of distributed generation development in Lithuania. Energy Policy 2011, 39, 4656-4663. [CrossRef]

76. Kaundinya, D.P.; Balachandra, P.; Ravindranath, N.H.; Ashok, V. A GIS (geographical information system)-based spatial data mining approach for optimal location and capacity planning of distributed biomass power generation facilities: A case study of Tumkur district, India. Energy 2013, 52, 77-88. [CrossRef]

77. Śleszyński, P.; Sudra, P. Zastosowanie metody minimalnego drzewa rozpinającego (najkrótszego dendrytu) w ocenie efektywności i spójności sieci osadniczej województwa mazowieckiego. Przegląd Geogr. 2019, 91, 61-80. [CrossRef]

78. Wielgosiński, G.; Czerwińska, J. Smog Episodes in Poland. Atmosphere 2020, 11, 277. [CrossRef]

79. Gawlikowska, A.P. Odnawialne źródła energii w planowaniu przestrzennym na przykładzie energetyki wiatrowej. Kwart. Archit. I Urban. 2013, 58, 131-159.

80. Tomczak, A. Otwarty Krajobraz Kulturowy z Zabytkiem w Tle. Formy Ochrony Przyrody na Przykładach z Ziemi Łódzkiej; Politechnika Łódzka: Łódź, Poland, 2018.

81. Stremke, S.; Koh, J. Sustainable energy transition: Properties and constraints of regenerative energy systems with respect to spatial planning and design. In Proceedings of the 3rd CIB International Conference on Smart and Sustainable Built Environments, Department(s) Landscape Architecture and Spatial Planning, WIMEK, Delft, The Netherlands, 15-19 June 2009.

82. Legutko-Kobus, P. Partycypacja jako element programowania rozwoju lokalnego. Studia Z Polityki Publicznej 2018, 3 , 45-58. [CrossRef]

83. Holtmeyer, M.L.; Wang, S.; Axelbaum, R.L. Considerations for decision-making on distributed power generation in rural area. Energy Policy 2013, 63, 708-715. [CrossRef]

84. Markowski, T. Main Issues in the Spatial Development of Poland in the European Context. Eur. Spat. Res. Policy 2007, 14, 7-29.

85. Berisha, E.; Cotella, G.; Janin-Rivolin, U.; Solly, A. Spatial governance and planning systems and the public control of spatial development: A European typology. Eur. Plann. Stud. 2020, 29, 181-200. [CrossRef]

86. Nadin, V.; Stead, D. Spatial planning in the United Kingdom 1990-2013. In Spatial Planning Systems and Practices in Europe. A Comparative Perspective on Continuity and Changes; Reimer, M., Getimis, P., Blotevogel, H., Eds.; Routledge: New York, NY, USA, 2014; pp. 198-214, ISBN 9780415727242.

87. Muñoz-Gielen, D. Urban governance, property rights, land readjustment and public value capturing. Eur. Urban. Reg. Stud. 2014, 21, 60-78. [CrossRef]

88. Zerriffi, H. Rural Electrification Strategies for Distributed Generation; Springer: Vancouver, BC, Canada, 2011. [CrossRef]

89. Szlachta, J. Agenda Terytorialna Unii Europejskiej 2030 jako podstawa kształtowania europejskiej polityki przestrzennej. In Polityka Przestrzenna w Czasie Kryzysu; Nowak, M., Ed.; Scholar: Warsaw, Poland, 2021; pp. 139-156.

90. Geography of COVID-19 Outbreak and First Policy Answers in European Regions and Cities; Espon Study; Policy Brief; EconomiX: Luxembourg, 2020.

91. Bouzarovski, S.; Tirado Herrero, S. Geographies of injustice: The socio-spatial determinants of energy poverty in Poland, the Czech Republic and Hungary. Post-Communist Econ. 2017, 29, 27-50. [CrossRef]

92. Śleszyński, P.; Bański, J.; Degórski, M.; Komornicki, T. Delimitation of problem areas in Poland. Geogr. Pol. 2017, 90, 131-138. [CrossRef] 